\title{
Tolerance to morphine analgesia: Influence of pain and method of morphine delivery
}

Scott A Chen MSc, Anthony L Vaccarino PhD

\author{
SA Chen, AL Vaccarino. \\ Tolerance to morphine analgesia: Influence of pain and \\ method of morphine delivery. \\ Pain Res Manage 2000;5(4):279-285.
}

Whether some kinds of pain can modify the development of tolerance to morphine analgesia is a controversial issue. Clinically, the development of tolerance is often difficult to establish because many factors can contribute to a decline in analgesic coverage, including disease progression. Basic animal research designed to examine tolerance provides the experimental control necessary to differentiate 'real' tolerance from other variables that can influence morphine analgesia. The present study examines the effects of inflammation induced by complete Freund's adjuvant (CFA) on the development of tolerance to morphine analgesia produced by two different methods of morphine delivery - repeated bolus injections and continuous infusion. Male Long-Evans hooded rats were injected with CFA $(0.2 \mathrm{~mL})$ into the right hind paw under sodium pentobarbital anesthesia or were given anesthesia alone. Starting $24 \mathrm{~h}$ later, rats either received an injection of morphine $(20 \mathrm{mg} / \mathrm{kg}$, intraperitoneal) on four consecutive days or were implanted with a $72 \mathrm{~h}$ osmotic minipump that delivered $80 \mathrm{mg} / \mathrm{kg}$ morphine over a similar time period. Control animals received saline injections or were implanted with empty minipumps. After $24 \mathrm{~h}$, sensitivity to morphine-induced analgesia was measured by the tail-immersion test (water maintained at $52^{\circ} \mathrm{C}$ ) using a cumulative dosing procedure. It was found that CFA attenuated tolerance to the morphine analgesia that was induced by intraperitoneal injections of morphine. In contrast, when morphine was delivered via osmotic minipumps, significant analgesic tolerance was observed in animals that received morphine in the presence of CFA but not in those that received morphine in the absence of CFA. These results show the importance of the method used to deliver morphine in determining the effects of pain on the development of tolerance to morphine analgesia.

Key Words: Analgesia; Complete Freund's adjuvant; Morphine; Pain; Tolerance

\section{Tolérance à l'analgésie produite par la morphine : incidence de la douleur et du mode d'administration}

RÉSUMÉ : Différents types de douleur peuvent-ils modifier l'installation de la tolérance à la morphine? Voilà une question controversée. La tolérance à la morphine est difficile à établir en clinique en raison de l'existence de nombreux facteurs qui peuvent avoir une incidence sur la diminution de l'analgésie, notamment la progression de la maladie. La recherche fondamentale menée chez l'animal, visant à étudier le phénomène de la tolérance dispose du milieu expérimental nécessaire pour différencier la « vraie » tolérance des autres variables qui peuvent influer sur l'analgésie à la morphine. Le présent article fait état des effets de l'inflammation provoqués par un adjuvant complet de Freund (ACF) sur l'apparition de la tolérance à l'analgésie produite par la morphine, suivant deux modes d'administration : les embols répétés ou les perfusions continues. Des rats mâles à capuchon Long-Evans ont reçu ou bien un ACF $(0,2 \mathrm{ml})$ dans l'arrière-patte droite sous anesthésie au pentobarbital sodique ou bien un analgésique seul. Vingt-quatre heures plus tard, certains rats ont reçu une injection de morphine $(20 \mathrm{mg} / \mathrm{kg}$ ) par voie intrapéritonéale, et ce, durant quatre jours consécutifs, tandis que d'autres ont été soumis à une perfusion de morphine administrée à raison de $80 \mathrm{mg} / \mathrm{kg}$ durant une période équivalente à l'aide d'une minipompe osmotique. Les animaux témoins, pour leur part, ont reçu des injections de solution saline ou se sont vu poser des minipompes vides. On a mesuré, au bout de $24 \mathrm{~h}$, le degré d'analgésie à l'aide de l'épreuve de l'immersion de la queue (eau maintenue à $52^{\circ} \mathrm{C}$ ) en tenant compte de la dose cumulative. On a constaté que l'ACF atténuait la tolérance à l'analgésie produite par les injections intrapéritonéales de morphine; au contraire, on a observé un degré élevé de tolérance à l'analgésie lorsque la morphine était administrée à l'aide des minipompes osmotiques chez les animaux ayant reçu l'ACF, mais non chez ceux qui n'en avaient pas reçu. Les résultats montrent bien l'importance du mode d'administration de la morphine pour déterminer les effets de la douleur sur l'installation de la tolérance à l'analgésie. 
Tn his paper entitled "The tragedy of needless pain" (1), Ronald Melzack provided a brief history of the use of opiates for pain control and highlighted instances in which patients often receive unsatisfactory pain relief. Among the factors identified as contributing to inadequate pain management was the restricted use of narcotics due to the fear that drug tolerance would develop, thus rendering it ineffective. The loss of morphine's analgesic benefit is indeed a significant problem in pain management because dose escalation can lead to undesirable side effects (ie, constipation) and decreased patient satisfaction. However, evaluation of clinical observations can be difficult and sometimes misinterpreted, because variables other than tolerance can contribute to a decline in analgesic coverage over time. These variables include progression of the disease, resulting in increased pain requiring greater amounts of morphine (1-5); the development of hyperalgesic states occuring after an injury that are less responsive to opiate treatment $(6,7)$; and, as recently suggested, the possibility that tumours may act as 'traps', thus preventing opiates from reaching their target sites to produce analgesia (8). Because of the complex issues encountered in the clinical setting and the inherent difficulties in controlling them, there is little, if any, direct clinical evidence of the degree to which tolerance contributes to the reduced analgesic effect of morphine over time. In fact, there is a growing body of literature suggesting that, although tolerance may develop in nonpain-related states, in the presence of pain, tolerance is not a major concern $(1,4,9)$. For example, in a recent study by Sloan and Melzack (10) conducted at the Palliative Care Unit at the Royal Victoria Hospital in Montreal, Quebec, it was found that $82 \%$ of cancer patients reported satisfactory pain relief, with no evidence of patients requiring rapidly escalating amounts of morphine.

Basic animal research designed to examine tolerance provides the experimental control necessary to differentiate 'real' tolerance from other variables that can influence morphine analgesia. The experimental paradigms used in animal studies can be defined based on whether pain is present or absent during the tolerance induction phase. In the majority of studies, morphine is administered in the absence of ongoing pain. Under these 'pain-free' conditions, tolerance to morphine analgesia is generally shown to occur by using a variety of experimental paradigms (11-13). These results have, in turn, been used by some clinicians as support that repeated exposure to opiates unequivocally leads to analgesic tolerance. However, administering morphine without pain is clearly unlike the clinical use of opiates, which are administered during ongoing pain.

Under conditions of pain, the results are conflicting, because some studies have reported that tolerance is unaffected or increased when morphine is administered in the presence of pain (14-25), whereas others have reported that pain attenuates or prevents tolerance $(23,24,26-37)$. The reasons for these discrepancies are not clear but may be related to differences in experimental paradigms, including the type and intensity of pain test used, and the dose and route of morphine delivery. To elucidate further the variables that determine the development of tolerance to morphine analgesia, we as- sessed the effects of pain on tolerance induced by different methods of morphine administration. In particular, we examined the effects of complete Freund's adjuvant (CFA) on tolerance induced by daily, intermittent, intraperitoneal injections of morphine versus tolerance induced by the continuous infusion of morphine via an osmotic minipump.

\section{ANIMALS AND METHODS}

\section{Animals}

Male Long-Evans hooded rats weighing 300 to $400 \mathrm{~g}$ were used as subjects. Rats were housed individually with free access to food and water, and were maintained on a $12 \mathrm{~h}$ light-dark cycle (light onset at 07:00). The experiments were carried out in accordance with the ethical guidelines of the International Association for the Study of Pain (38). All protocols and procedures were approved by the University of New Orleans Institutional Animal Care and Use Committee (New Orleans, Louisiana).

\section{CFA}

CFA-modified (Calbiochem, USA) was composed of killed and dried microbial cells suspended in an emulsifying oil. Under light sodium pentobarbital anesthesia $(50 \mathrm{mg} / \mathrm{kg}$ intraperitoneal), rats received an injection of $0.2 \mathrm{~mL} \mathrm{CFA}$ into the plantar surface of the right hind paw. Control animals received anesthesia alone. CFA is a frequently used model of inflammationrelated pain, which, when injected into the footpad, produces localized inflammation that appears within $2 \mathrm{~h}$, peaks at four days and lasts about three weeks $(39,40)$.

\section{Tolerance induction}

In experiment 1, morphine sulphate (Paddock, USA) was dissolved in physiological saline and administered intraperitoneal in a volume of $0.1 \mathrm{~mL} / 100 \mathrm{~g}$ body weight. Starting $24 \mathrm{~h}$ after the CFA injection, rats were given a single daily injection of either morphine sulphate $(20 \mathrm{mg} / \mathrm{kg}$ intraperitoneal $)$ or an equal volume of saline on four consecutive days (ie, the last injection was given $72 \mathrm{~h}$ after the first injection). Thus, there were four groups: no pain and saline $(n=14)$, no pain and morphine $(n=15)$, pain and saline $(n=15)$, and pain and morphine $(\mathrm{n}=14)$. In experiment $2,24 \mathrm{~h}$ after CFA administration, rats were placed under sodium pentobarbital anesthesia (50 mg/kg intraperitoneal) and a $72 \mathrm{~h}$ osmotic minipump was implanted in the upper back (posterior to the scapulae) (ALZA, USA) filled with morphine. A total of $80 \mathrm{mg} / \mathrm{kg}$ of morphine was infused at a rate of $1.1 \mathrm{mg} / \mathrm{kg} / \mathrm{h}$ over a $72 \mathrm{~h}$ period. Control animals were also placed under anesthesia, but empty pumps (placebos) were implanted. Thus, there were four groups in this experiment: no pain and a placebo pump $(n=9)$, no pain and a morphine pump $(\mathrm{n}=10)$, pain and a placebo pump $(n=10)$, and pain and a morphine pump $(n=10)$.

\section{Morphine analgesia}

Animals were tested for analgesia by the tail-immersion test $24 \mathrm{~h}$ after tolerance induction, using a cumulative dosing procedure as previously described (41). With the animal loosely wrapped in a cloth, the distal third of the tail was immersed in water maintained at $52 \mathrm{C}$. The latency to flick the tail was re- 


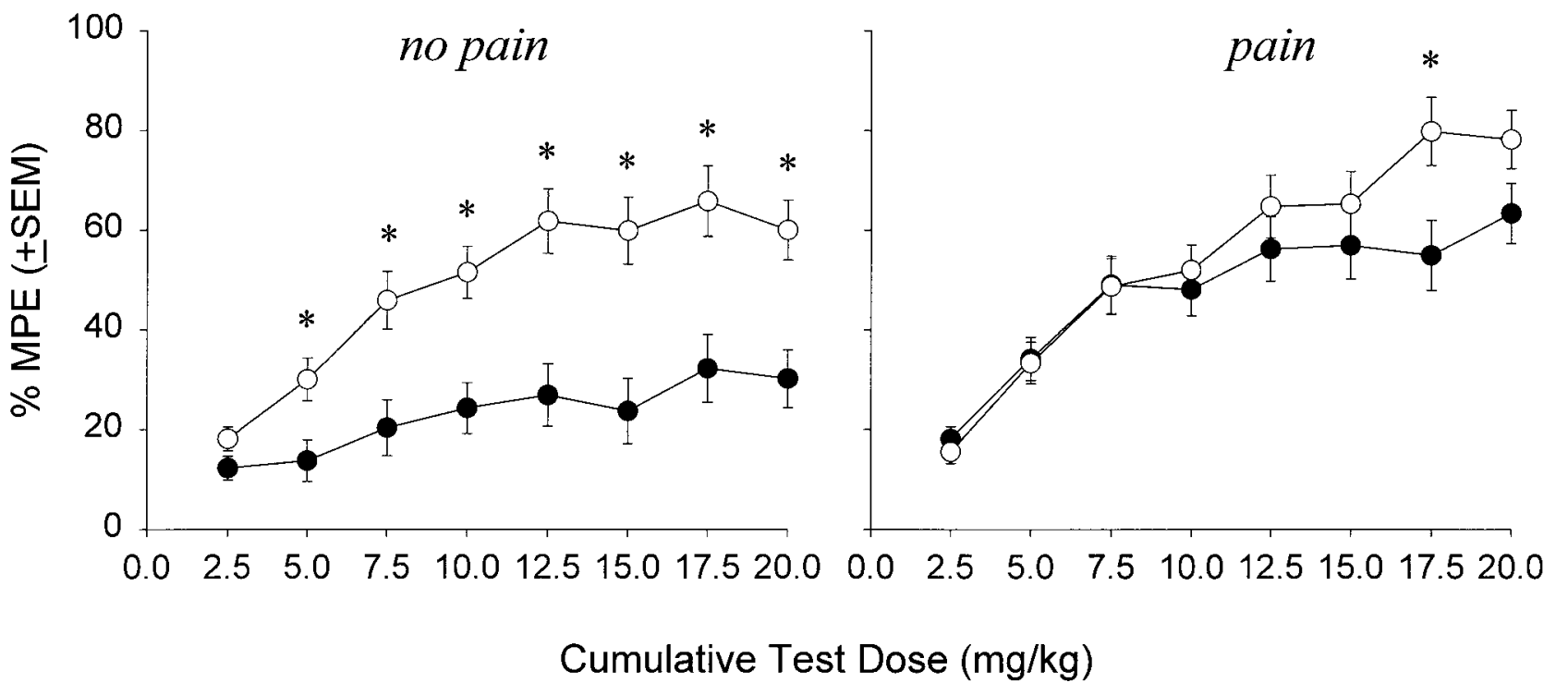

Figure 1) Effects of complete Freund's adjuvant on tolerance induced by intraperitoneal injections of morphine. The data are expressed as percentage maximal possible effect (MPE) ( SEM) across eight cumulative test doses of morphine. Rats received intraperitoneal injections of saline (o) or $20 \mathrm{mg} / \mathrm{kg}$ morphine ( ) for four consecutive days in the absence (no pain, left panel) or presence (pain, right panel) of complete Freund's adjuvant. * $\mathrm{P}<0.05$

corded, and a $10 \mathrm{~s}$ cutoff period was imposed to prevent tissue damage. After a baseline measure was taken, each animal was injected with morphine $(2.5 \mathrm{mg} / \mathrm{kg}$ intraperitoneal $)$ and was tested for analgesia 30 min later. Immediately after testing, each animal was injected again with morphine $(2.5 \mathrm{mg} / \mathrm{kg})$ and tested $30 \mathrm{~min}$ later. This procedure was repeated to a cumulative dose of $20 \mathrm{mg} / \mathrm{kg}$ (ie, a total of eight $2.5 \mathrm{mg} / \mathrm{kg}$ injections), with one analgesic measure taken after each dose. Because CFA has been shown to produce hyperalgesia that is restricted to the affected area $(42,43)$, the tail-immersion procedure was chosen to measure analgesia as opposed to sensitivity of the CFA-treated paw that may be confounded by the development of hyperalgesia in that area.

\section{STATISTICAL ANALYSIS}

Data obtained in the tail immersion test were expressed as percentage of maximal possible effect (MPE) using the following formula:

$$
\% \text { Maximal possible effect } \frac{\text { (test latency - baseline latency) } x 100}{\text { cutoff - baseline latency }}
$$

Thus, $0 \%$ indicated no change from baseline, and $100 \%$ indicated the maximal possible increase. Using SPSS Version 8.0 (SPSS Inc, USA), tail immersion data were analyzed separately for pain conditions and methods of morphine delivery. This was completed with a 28 mixed ANOVA using the factors of morphine (morphine, saline or placebo) and test dose $(2.5,5,7.5,10,12.5,15,17.5$ and $20 \mathrm{mg} / \mathrm{kg})$.

\section{RESULTS}

In experiment 1 , ANOVA revealed a significant interaction between morphine and test dose for both 'no pain' $(\mathrm{F}[7,189]=4.74, \mathrm{P}<0.01)$ and 'pain' $(\mathrm{F}[7,189]=2.63, \mathrm{P}<0.01)$ conditions (Figure 1). An analysis of the simple comparisons of morphine within test dose in the 'no pain' condition revealed that less analgesia was produced in morphine-pretreated animals in the 5 to $20 \mathrm{mg} / \mathrm{kg}$ cumulative dose range than in saline-pretreated animals $(\mathrm{P}<0.05)$. In contrast, in the 'pain' condition, less analgesia was produced in morphine-pretreated animals at only the $17.5 \mathrm{mg} / \mathrm{kg}$ cumulative dose than in saline- pretreated animals $(\mathrm{P}<0.05)$. These results indicate that rats that had received daily intraperitoneal injections of morphine in the presence of CFA showed less analgesic tolerance than those that had received morphine in the absence of CFA.

In experiment 2, ANOVA in the 'no pain' condition revealed no main effect for morphine $(F[1,17]=1.60$, not significant) and no interaction between morphine and test dose $(F[7,119]=0.79$, not significant) (Figure 2), indicating that analgesic tolerance did not develop under these conditions. In contrast, in the 'pain' condition, ANOVA revealed a significant main effect for morphine $(\mathrm{F}[1,18]=8.80, \mathrm{P}<0.01)$ but no interaction between morphine and test dose $(F[7,126]=1.75$, not significant), indicating that analgesic tolerance developed in these animals at all cumulative test doses of morphine (Figure 2). Furthermore, no differences in baseline response were noted between morphine-pretreated animals and placebo pump controls ( $F[1,37]=0.80$, not significant), suggesting that no residual analgesic effects of morphine remained in the pump at the time of testing. These results indicate that significant analgesic tolerance was observed in the animals that received morphine via osmotic minipumps in the presence of CFA but not in the absence of CFA. Although not compared statistically, it also appears that the effects of morphine were lower in the rats that received placebo pumps than in those that received saline injections (see Figures 1 and 2). The reasons for this difference are not clear, but may be related to the surgical procedures and/or general anesthetic used during pump implantation. 


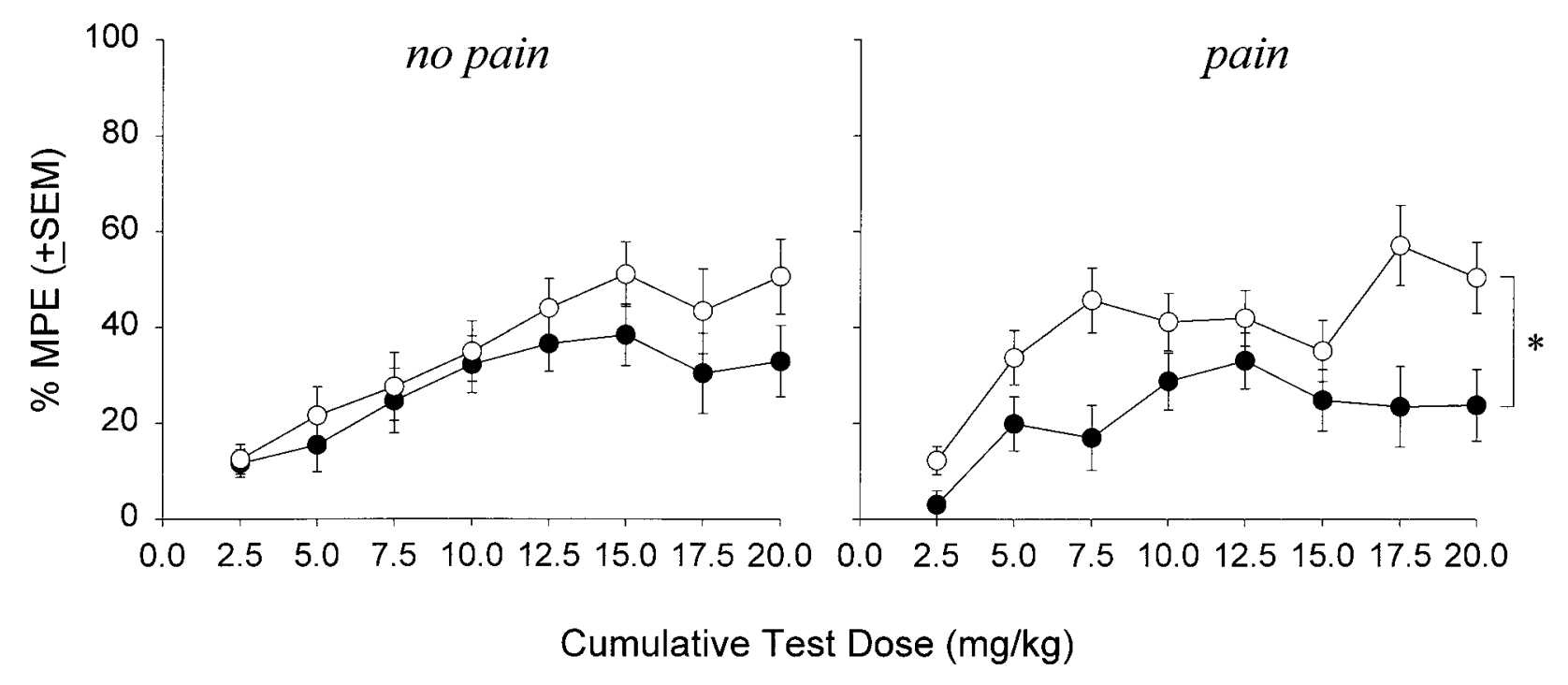

Figure 2) Effects of complete Freund's adjuvant on tolerance induced by continuous infusion of morphine. The data are expressed as percentage maximal possible effect (MPE) ( SEM) across eight cumulative test doses of morphine. Rats were implanted with a placebo minipump (o) or a morphine minipump ( ), infusing a total of $80 \mathrm{mg} / \mathrm{kg}$ of morphine over four consecutive days in the absence (no pain, left panel) or presence (pain, right panel) of complete Freund's adjuvant.*Significant main effect of morphine $(P<0.01)$

\section{DISCUSSION}

The present study shows that CFA attenuates the development of tolerance to morphine analgesia produced by daily intraperitoneal injections of morphine. In contrast, when the same total amount of morphine was delivered via osmotic minipumps, tolerance was observed in animals that received morphine in the presence of CFA but not in the absence of CFA. Because analgesic testing was only performed after the tolerance induction phase, it cannot be determined from the present study whether the analgesic effects of morphine were of comparable magnitude during the tolerance induction phase. Analgesic testing was omitted during that phase to minimize the role of associative cues that could possibly influence the development of tolerance (44).

The lack of tolerance observed after daily bolus intraperitoneal injections of morphine in the presence of CFA is consistent with that found in previous studies on inflammationrelated pain. For example, rats inoculated with CFA in the base of the tail that were allowed to self-administer morphine intravenously showed less analgesic tolerance than pain-free controls (30), and tolerance was not observed to the narcotic bezitramide when given by repeated oral administrations in CFA-treated rats (45). Similarly, tolerance was attenuated in rats given bolus (intraperitoneal or subcutaneous) injections of morphine in the presence of formalin-induced pain $(23,24,32-$ 37). Taken together, these results provide further evidence for the ability of pain to prevent or attenuate the development of tolerance to morphine analgesia, which parallels the clinical literature suggesting that tolerance is not a major concern when morphine is used to treat pain (1).

In contrast to the above studies, however, others have found that repeated bolus administrations of morphine produced tolerance despite the presence of CFA $(18,19,23)$. The reasons for these discrepancies are not clear, but may be related to several differences in experimental paradigms. One possibility is the nociceptive stimuli used to measure tolerance. The present study tested for morphine analgesia to a nociceptive stimulus applied to the tail, whereas Kayser and Guilbaud (18) and Kayser et al (19) used vocalization thresholds to pressure applied to the inflamed paw. Because CFA has been shown to produce hyperalgesia restricted to the affected area $(42,43)$, use of vocalization thresholds to pressure applied to the inflamed paw to measure analgesia may be confounded by the development of hyperalgesia in that area.

Another important methodological difference to consider is the volume of CFA used. When injected into the footpad, $0.02 \mathrm{~mL}$ of CFA was not found to affect tolerance induced by five daily subcutaneous injections of $10 \mathrm{mg} / \mathrm{kg}$ morphine (23). This is in contrast to the effect of formalin-induced pain, which was found to decrease tolerance induced by the same regimen of morphine (23). The reasons for the differences between the effects of formalin pain and CFA in that study are not known, but may be related to different neural substrates that mediate morphine analgesia in different types of pain (46-48). Alternatively, it is possible that this difference is related to the pain intensity of the two stimuli, because the amount of paw inflammation, which may provide an index of pain, is greater after formalin than after $0.02 \mathrm{~mL}$ of CFA (23). In the present study, when a 10 -fold higher volume of CFA was used $(0.2 \mathrm{~mL})$, tolerance induced by comparable amounts of morphine (four daily injections of $20 \mathrm{mg} / \mathrm{kg}$ ) was reduced. This explanation is consistent with the hypothesis proposed by Colpaert (49), who stated that the development of tolerance during pain depends on the intensity of the pain stimulus relative to the amount of analgesic, such that tolerance develops when the amount of pain is low relative to the amount of 
analgesic, and vice versa. This may also explain the finding by Kayser and Guilbaud (18) that rats inoculated with CFA in the base of the tail developed tolerance when given relatively high amounts of morphine (increasing doses of morphine over four consecutive days of 40,80, 120 and $160 \mathrm{mg} / \mathrm{kg}$ ), beyond what is necessary to control the pain (49). Therefore, there may exist a critical threshold of pain intensity relative to the amount of morphine that determines the ability of pain to attenuate tolerance (49).

The mechanisms that mediate the attenuation of tolerance induced by daily injections of morphine observed in the present study may be related to a pain-induced activation of the hypothalamic-pituitary-adrenal axis, which is well known to respond to stressful stimuli (50-52). It has been shown that experimental stress blocks the development of tolerance to morphine analgesia in intact mice but not in adrenalectomized ones (53). Furthermore, the blockade of tolerance by formalin-induced pain is prevented by the corticosterone synthesis inhibitor metyrapone (36) and is not observed in a strain of rat (Lewis) that shows low stress-induced hypothalamicpituitary-adrenal activity (24). Besides stress, pain-associated anxiety may also contribute to the blockade of tolerance to morphine analgesia, because daily injections of diazepam (32) or the GABA-A receptor agonist muscimol (34) abolished the formalin-induced attenuation of tolerance. Taken together, these results suggest that the physiological consequences of pain-associated stress and/or anxiety may act to inhibit the development of morphine tolerance. It is also important to recognize that the analgesic and/or antihyperalgesic effects of morphine are enhanced in CFA-treated rats in both inflamed and noninflamed tissue $(22,42,54)$. The mechanisms that mediate enhanced morphine analgesia in CFA-treated rats are not fully understood but may be related to an increase in endogenous opiate peptides $(55,56)$ and/or a facilitation in pain inhibitory systems induced by inflammation (42). Therefore, it is possible that morphine analgesia in the present study was enhanced in CFA-treated rats, thus masking tolerance induced by repeated intraperitoneal injections of morphine.

In the present study, when the same volume of CFA $(0.2 \mathrm{~mL})$ and total amount of morphine $(80 \mathrm{mg} / \mathrm{kg})$ was used, CFA attenuated tolerance when morphine was administered by repeated intraperitoneal injections but not when morphine was continuously infused via an osmotic minipump. In fact, when morphine was delivered via osmotic minipumps, tolerance was observed only in animals that were given CFA during the tolerance induction period. A similar finding also has been reported after continuous infusion of morphine via pellet implants, in which CFA enhances the development of tolerance $(16,20)$. Therefore, although the presence or absence of pain is likely a key factor in determining the development of tolerance to morphine analgesia, the method in which morphine is administered is an important variable. Whether pain patients would benefit from intermittent bolus administration as opposed to continuous infusion is not known. It is interesting to note, however, that greater tolerance is observed in patients receiving postoperative morphine by continuous infusions than in those receiving morphine by repeated bolus injections (57).
The reasons for the differential effects of CFA on tolerance by the two methods of morphine delivery are not known, but may be related to the 'type' of tolerance induced. The development of tolerance to morphine analgesia has been shown to involve both associative and nonassociative mechanisms (44). Associative tolerance involves learning an association between the environment and/or drug delivery (ie, handling, injection procedures, etc) and the effects of the drug. This is suggested to result in the development of a compensatory response to the drug effects, thus reducing its effectiveness (44). Tolerance induced by repeated intraperitoneal injections of morphine should favour the development of associative-type tolerance. On the other hand, when no cues are associated with morphine delivery, tolerance is defined as nonassociative or pharmacological, resulting from pharmacokinetic (dispositional) or neural (pharmacodynamic) changes. Tolerance induced by the continuous infusion of morphine would likely favour this type of tolerance (ie, nonassociative or pharmacological). Because different neural mechanisms likely mediate associative and nonassociative tolerance (58), it may explain the differential effects of CFA on tolerance induced by repeated intraperitoneal injections compared with continuous infusions. Furthermore, because continuous administration of morphine would result in continuous receptor occupancy and stimulation, it is perhaps more likely to produce pharmacodynamic changes, whereas receptor-based changes after intermittent injections may be minimized because of alternating periods of receptor occupancy $(59,60)$. Another possibility is that the differential effects of CFA induced by these two methods of delivery may be related to their different effects on endogenous opiate systems, because studies have shown that intermittent injections of morphine decrease levels of pituitary dynorphin (61), whereas continuous infusion of morphine increases them (62).

\section{CONCLUSIONS}

Previous studies have often led to conflicting results as to the influence of pain on the development of morphine tolerance. Much of this confusion can be attributed to differences in both the types of pain tests used, and the doses and route of morphine administration. In the present study, we attempted to reconcile some of these issues by using the same pain test and the same total amount of morphine, but different methods of morphine delivery. Under these conditions, we showed a dissociation between the ability of pain to block tolerance induced by different methods of morphine delivery, such that pain blocks the development of tolerance induced by daily bolus injections but possibly enhances tolerance induced by continuous infusion of morphine.

ACKNOWLEDGMENTS: As the graduate mentor of Anthony L Vaccarino, Professor Ronald Melzack was a major source of knowledge and inspiration that stemmed not only from his vast research and theoretical writings, but also from his true compassion for those who suffered pain. Anthony Vaccarino gratefully acknowledges the invaluable support and friendship Dr Melzack has provided over the years. This study was supported by NIDA grant DA 11839 . 


\section{REFERENCES}

1. Melzack R. The tragedy of needless pain. Sci Am 1991;262:27-33.

2. Collin E, Poulain P, Gauvin-Piquard A, Petit G, Pichard-Leandri E. Is disease progression the major factor in morphine 'tolerance' in cancer pain treatment? Pain 1993;55:319-26.

3. Foley KM. Changing concepts of tolerance to opioids: what the cancer patient has taught us. In: Chapman CR, Foley KM, eds. Current and Emerging Issues in Cancer Pain: Research and Practice. New York: Raven Press, 1993:331-50.

4. Portenoy RK. Opioid tolerance and responsiveness: research findings and clinical observations. In: Gebhardt GF, Hammond DL, Jenson TS, eds. Proceedings of the 7th World Congress of Pain. Seattle: IASP Press, 1994:595-619.

5. Twycross RG. Opioids. In: Wall PD, Melzack R, eds. Textbook of Pain, 3rd edn. London: Churchill Livingston, 1994:943-62.

6. Coderre TJ, Katz J, Vaccarino AL, Melzack R. Contribution of central neural plasticity to pathological pain: review of clinical and experimental evidence. Pain 1993;42:259-85.

7. Mao J, Price DD, Mayer DJ. Mechanisms of hyperalgesia and morphine tolerance: a current view of their possible interactions. Pain 1995;62:259-74.

8. Arcuri E. Can tumors act as opioid traps, mimicking opioid tolerance? J Pain Symptom Manage 1998;16:78-9.

9. Vaccarino AL. Tolerance to morphine analgesia: Basic issues to consider. Pain Forum 1999;8:25-8.

10. Sloan P, Melzack R. Long-term patterns of morphine dosage and pain intensity among cancer patients. Hosp J 1999;14:35-47.

11. Detweiller DJ, Rhode DS, Basbaum AI. The development of opioid tolerance in the formalin test in the rat. Pain 1995;63:251-4.

12. Louie AK, Way EL. Overview of opiate tolerance and physical dependence. In: Almeida OF, Shippenberg TS, eds. Neurobiology of Opioids. New York: Springer, 1991.

13. Mucha RF, Kalant H, Linseman JA. Quantitative relationships among measures of morphine tolerance and physical dependence. Pharm Biochem Behav 1979;10:397-405.

14. Catheline G, Kayser V, Idanpaan-Heikkila JJ, Guilbaud G. The antinociceptive activity of kappa- but not delta-opioid receptor agonists is maintained in morphine-tolerant neuropathic rats. Eur J Pharmacol 1996;318:273-81.

15. Christensen D, Guilbaud G, Kayser V. Complete prevention but stimulus-dependent reversion of morphine tolerance by the glycine/NMDA receptor antagonist (+)-HA966 in neuropathic rats. Anesthesiology 2000;92:786-94.

16. Gutstein AH, Lanthorn TH, Akil H. Does chronic nocieptive stimulation alter the development of morphine tolerance? Brain Res 1995;680:173-9.

17. Idanpaan-Heikkila J, Guilbaud G, Kayser V. Prevention of tolerance to the antinociceptive effects of systemic morphine by a selective cholecystokinin-B receptor antagonist in a rat model of peripheral neuropathy. J Pharmacol Exp Ther 1997;282:1366-72.

18. Kayser V, Guilbaud G. Can tolerance to morphine be induced in arthritic rats? Brain Res 1985;334:335-8.

19. Kayser V, Neil A, Guilbaud G. Repeated low doses of morphine induces rapid tolerance in arthritic rats but a potentiation of opiate analgesia in normal rats. Brain Res 1986;383:392-6.

20. Li JY, Wong CH, Huang KS, et al. Morphine tolerance in arthritic rats and serotonergic system. Life Sci 1999;64:PL111-6.

21. Mao J, Price DD, Mayer DJ. Thermal hyperalgesia in association with the development of morphine tolerance: roles of excitatory amino acid receptors and protein kinase. J Neurosci 1994;14:2301-12.

22. Neil A, Kayser V, Gacel G, Besson J-M, Guilbaud G. Opioid receptor types and antinociceptive activity in chronic inflammation: both kappa- and mu-opiate agonistic effects are enhanced in arthritic rats. Eur J Pharmacol 1986;130:203-8.

23. Rahman AFM, Takahashi M, Kaneto H. Development of tolerance to morphine antinociception in mice treated with nociceptive stimulants. Jpn J Pharmacol 1993;63:59-64.

24. Vaccarino AL, Couret LC Jr. Relationship between hypothalamic- pituitary-adrenal activity and blockade of tolerance to morphine analgesia by pain: a strain comparison. Pain 1995;63:385-9.

25. Yu W, Hao J-X, Xu X-J, Wiesenfeld-Hallin Z. The development of morphine tolerance and dependence in rats with chronic pain. Brain Res 1997;756:141-6.

26. Backonja M, Miletic G, Miletic V. Morphine analgesia of the chronic thermal hyperalgesia due to sciatic constriction in the rat. Neurosci Lett 1995;196:61-4.

27. Chu KS, Chen HP, Kang FC, Tsai YC. Prolonged morphine treatment relieves thermal hyperalgesia in rats with sciatic nerve constriction injury. Kao Hsiung I Hsueh Ko Hsueh Tsa Chih 2000;16:20-5.

28. Ho ST, Wang JJ, Liaw WJ, Lee HK, Lee SC. Surgical pain attenuates acute morphine tolerance in rats. Br J Anaesth 1999;82:112-6.

29. Lerida M, Sanchez-Blazquez P, Garzon J. Incidence of morphine withdrawal and quasi-abstinence syndrome in a model of chronic pain in the rat. Neurosci Lett 1987;81:155-8.

30. Lyness WH, Smith FL, Heavner JE, Iacono CU, Garvin RD. Morphine self-administration in the rat during vasopressin. Endocrinol 1989;116:966-70.

31. Neil A, Kayser V, Chen YL, Guilbaud G. Repeated low doses of morphine do not induce tolerance but increase opioid antinociceptive effects in rats with peripheral neuropathy. Brain Res 1990;522:140-3.

32. Rahman AFM, Takahashi M, Kaneto H. Involvement of pain associated anxiety in the development of tolerance in formalin treated mice. Jpn J Pharmacol 1994;65:313-7.

33. Rahman AFM, Takahashi M, Kaneto H. Morphine dependence with or without tolerance in formalin-treated mice. Jpn J Pharmacol 1994;66:277-80.

34. Rahman AF, Takahashi M, Kaneto H. Role of GABAergic systems in the development of morphine tolerance in formalin-treated mice. Jpn J Pharmacol 1995;68:207-11.

35. Vaccarino AL, Marek P, Kest B, et al. Morphine fails to produce tolerance when administered in the presence of formalin pain in rats. Brain Res 1993;627:287-90.

36. Vaccarino AL, Nores WL, Soignier RD, Olson RD. The role of corticosterone in the blockade of tolerance to morphine analgesia by formalin-induced pain. Neurosci Lett 1997;232:139-42.

37. Bardin, L, Kim, JA, Siegel, S. The role of formalin-induced pain in morphine tolerance, withdrawal, and reward. Exp Clin Psychopharmacol 2000;8:161-7.

38. Committee for Research and Ethical Issues of the IASP. Ethical standards for investigations of experimental pain in animals. Pain 1983;16:109.

39. Iadarola MJ, Brady LS, Draisci G, Dubner R. Enhancement of dynorphin gene expression in spinal cord following experimental inflammation: stimulus specificity, behavioral parameters and opioid receptor binding. Pain 1988;35:313-26.

40. Stein C, Millan MJ, Herz A. Unilateral inflammation of the hindpaw in rats as a model of prolonged noxious stimulation: alterations in behavior and nociceptive thresholds. Pharmacol Biochem Behav 1988;31:455-51.

41. Duttaroy A, Kirtman R, Farrell F, et al. The effect of cumulative dosing on the analgesic potency of morphine in mice. Pharmacol Biochem Behav 1997;58:67-71.

42. Hurley RW, Hammond DL. The analgesic effects of supraspinal mu and delta opioid receptor agonists are potentiated during persistent inflammation. J Neurosci 2000;20:1249-59.

43. Millan MJ, Czlonkowski A, Morris B, et al. Inflammation of the hind limb as a model of unilateral, localized pain: influence on multiple opioid systems in the spinal cord of the rat. Pain 1988;35:299-312.

44. Macrae JR, Sole MT, Siegal S. The contribution of Pavlovian conditioning in drug tolerance and dependence. Br J Addiction 1987;82:371-80.

45. Colpaert FC. Can chronic pain be suppressed despite purported tolerance to narcotic analgesia? Life Sci 1979;24:1201-10.

46. Abbott FV, Melzack R, Samuel C. Morphine analgesia in tail-flick 
and formalin pain tests is mediated by different neural systems. Exp Neurol 1982;75:644-51.

47. Cohen SR, Abbott FV, Melzack R. Unilateral analgesia produced by intraventricular morphine. Brain Res 1984;303:277-87.

48. Matthies BK, Franklin KB. Formalin pain is expressed in decerebrate rats but not attenuated by morphine. Pain 1992;51:199-206.

49. Colpaert FC. System theory of pain and opiate analgesia: no tolerance to opiates. Pharmacol Rev 1996;48:355-402.

50. Banky Z, Nagy GM, Halasz B. Analysis of pituitary prolactin and adrenalcortical response to ether, formalin or restraint in lactating rats: rise in corticosterone, but no increase in plasma prolactic levels after exposure to stress. Neuroendocrinology 1994;59:63-71.

51. Friedman SB, Ader R, Grota LJ, Larson T. Plasma corticosterone response to parameters of electric shock stimulation in the rat. Psychosom Med 1967;29:323-8.

52. Sternberg EM, Glowa JR, Smith MA, et al. Corticotropin releasing hormone related behavioral and neuroendocrine responses to stress in Lewis and Fischer rats. Brain Res 1992;570:54-60.

53. Takahashi M, Sugimachi K, Kaneto H. Role of adrenal glucocorticoids in the blockade of the development of analgesic tolerance to morphine by footshock stress exposure in mice. Jpn J Pharmacol 1989;51:329-36.

54. Stein C, Millan MJ, Yassouridis A, Herz A. Antinociceptive effects of mu- and kappa-agonists in inflammation are enhanced by a peripheral opioid receptor-specific mechanism. Eur J Pharmacol 1988; 155:255-64

55. Ossipov MH, Kovelowski CJ, Porreca F. The increase in morphine antinociceptive potency produced by carrageenan-induced hindpaw inflammation is blocked by naltrindole, a selective delta-opioid antagonist. Neurosci Lett 1995;184:173-6.

56. Przewlocka B, Lason W, Przewlocki R. Time-dependent changes in the activity of opioid systems in the spinal cord of monoarthritic rats - a release and in situ hybridization study. Neuroscience 1992;46:209-16.

57. Marshall H, Porteous C, McMillan I, MacPherson SG, Nimmo WS. Relief of pain by infusion of morphine after operation: does tolerance develop? Br Med J (Clin Res Ed) 1985;291:19-21.

58. Grisel JE, Watkins LR, Maier SF. Associative and non-associative mechanisms of morphine analgesic tolerance are neurochemically distinct in the rat spinal cord. Psychopharmacology 1996;128:248-55.

59. Duttaroy A, Yoburn BC. The effect of intrinsic efficacy on opioid tolerance. Anesthesiology 1995;82:1226-36.

60. Feldman RS, Meyer JS, Quenzer LF. Principles of Neuropsychopharmacology. Massachusetts: Sinauer Associates Inc, 1997.

61. Nylander I, Vlaskovska M, Terenius L. The effects of morphine treatment and morphine withdrawal on the dynorphin and enkephalin systems in Sprague-Dawley rats. Psychopharmacology (Berl) 1995;118:391-400.

62. Rattan AK, Koo KL, Tejwani GA, Bhargava HN. The effect of morphine tolerance dependence and abstinence on immunoreactive dynorphin (1-13) levels in discrete brain regions, spinal cord, pituitary gland and peripheral tissues of the rat. Brain Res 1992;584:207-12. 


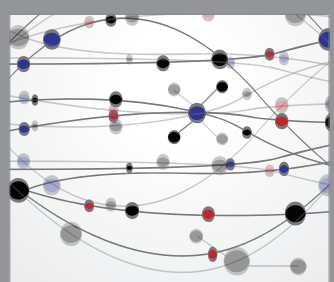

The Scientific World Journal
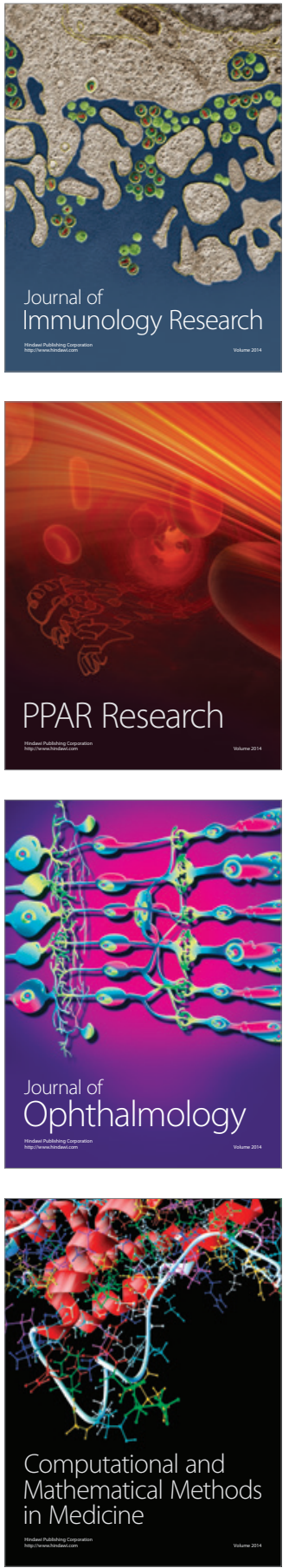

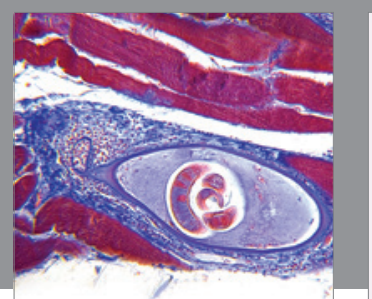

Gastroenterology Research and Practice

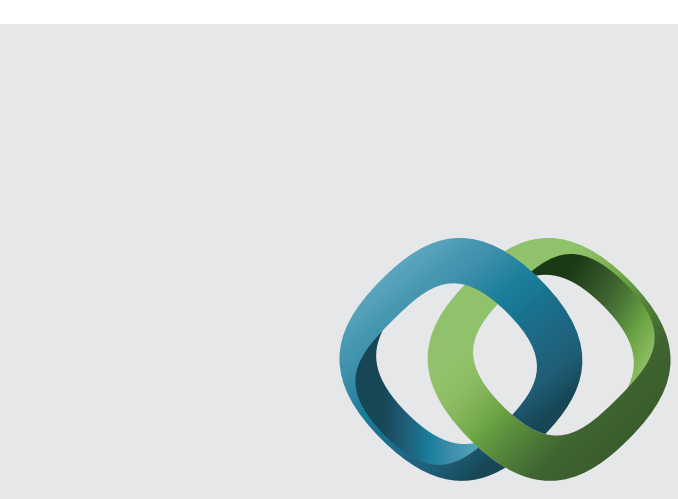

\section{Hindawi}

Submit your manuscripts at

http://www.hindawi.com
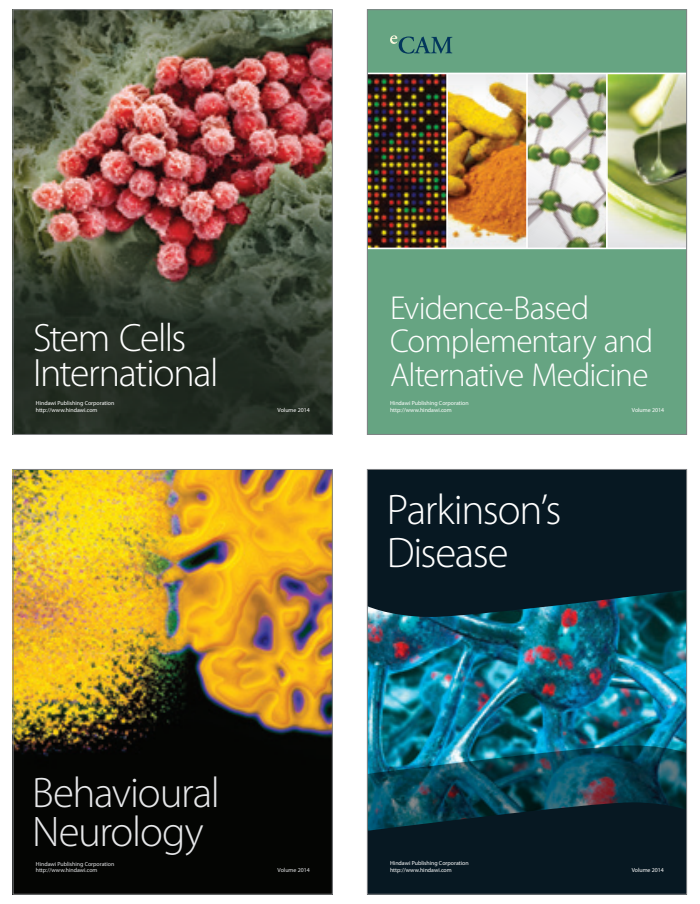
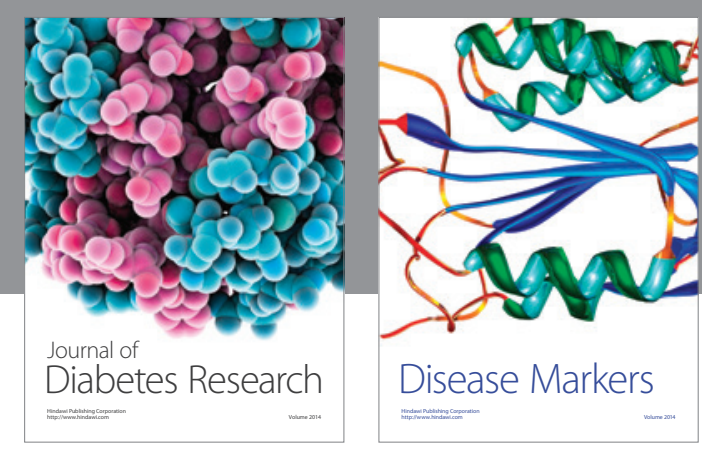

Disease Markers
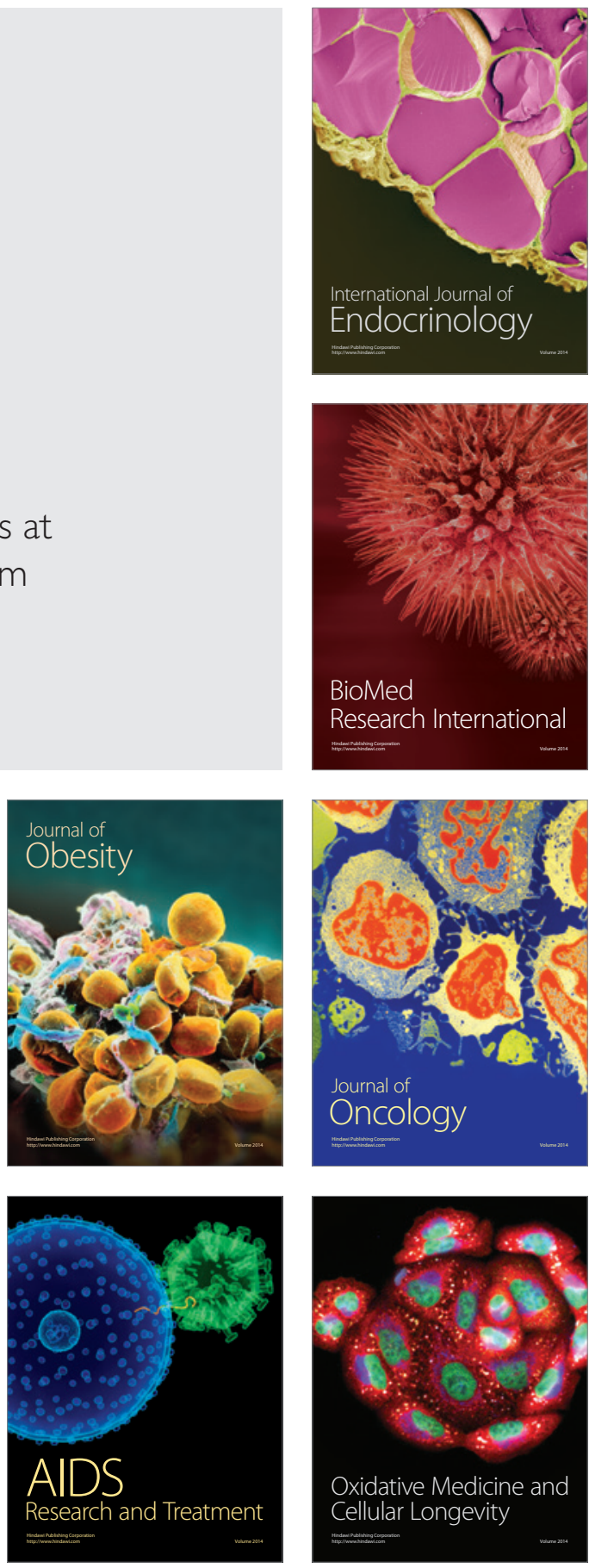